\title{
Simultaneous quantitative detection of viable Escherichia coli 0157:H7, Cronobacter spp., and Salmonella spp. using sodium deoxycholate-propidium monoazide with multiplex real-time PCR
}

\author{
Taobo Liang, ${ }^{1}$ Ping Zhou, ${ }^{1}$ Baoqing Zhou, ${ }^{1}$ Qian Xu, ${ }^{1}$ Ziqiang Zhou, ${ }^{1}$ Xin Wu, ${ }^{2}$ Zoraida P. Aguilar, ${ }^{3}$ \\ and Hengyi $\mathrm{Xu}^{1 *}$ \\ ${ }^{1}$ State Key Laboratory of Food Science and Technology, Nanchang University, Nanchang, 330047, P. R. China \\ ${ }^{2}$ Jiangxi Institute for Food Control, Nanchang, 330001, P. R. China \\ ${ }^{3}$ Zystein LLC, Fayetteville, AR 72703
}

\begin{abstract}
Escherichia coli O157:H7, Cronobacter spp., and Salmonella spp. are common food-borne pathogens in milk that may cause serious diseases. In the present study, we established a simple, rapid, and specific method to simultaneously detect viable E. coli O157:H7, Cronobacter spp., and Salmonella spp. in milk. Three specific genes, fliC from E. coli O157:H7, cgcA from Cronobacter spp., and invA from Salmonella spp., were selected and used to design primers and probes. False-positive results were eliminated with the use of a combined sodium deoxycholate (SD) and propidium monoazide (PMA) treatment. Using the optimized parameters, this SDPMA treatment combined with multiplex real-time PCR (SD-PMA-mRT-PCR) detected E. coli O157:H7, Cronobacter spp. and Salmonella spp. respectively, at $10^{2} \mathrm{cfu} / \mathrm{mL}$ in pure culture or artificially spiked skim milk samples. A reasonable recovery rate (from 100 to $107 \%$ ) for detection of viable bacteria using the SDPMA-mRT-PCR assay was obtained in the presence of dead bacteria at $10^{7} \mathrm{cfu} / \mathrm{mL}$. The SD-PMA-mRTPCR method developed in this study can accurately detect and monitor combined contamination with $E$. coli O157:H7, Cronobacter spp., and Salmonella spp. in milk and milk products.
\end{abstract}

Key words: multiplex real-time PCR, sodium deoxycholate, propidium monoazide, viable bacteria detection

\section{INTRODUCTION}

Food-borne diseases have become a major public health issue worldwide, and significant food contamina-

Received September 22, 2018.

Accepted December 20, 2018.

*Corresponding author: kidyxu@163.com or HengyiXu@ncu.edu.cn tion incidents have been confirmed, resulting in 7,890 illness, 83 deaths, and 9 miscarriages in the United States between 2000 and 2016 (Bhunia, 2018). A survey indicated that milk, the second most-consumed food product, is easily contaminated by food-borne pathogens (Painter et al., 2013). Among food-borne pathogens, Escherichia coli O157:H7, Cronobacter spp., and Salmonella spp. have been frequently reported as common disease-causing agents in milk (Kumar et al., 2013; Yu et al., 2017). Escherichia coli O157:H7 is a typical food-borne pathogen that causes serious human illness such as hemorrhagic colitis and hemolytic uremic syndrome at a low infectious dose, particularly in children under $5 \mathrm{yr}$ of age and adults over $60 \mathrm{yr}$, with a death rate of 5 to 10\% (Amani et al., 2015). Cronobacter spp. can cause severe meningitis, bacteremia, and necrotizing enterocolitis in neonates, with high mortality rates ranging between 40 and 80\% (Sulovská et al., 2017). In adults, most Cronobacter spp. infections occur in the elderly, especially those who have serious illnesses. Salmonella spp. have been involved in severe enteritis, typhoid fever, and even death (Coburn et al., 2007). Food-borne diarrheal disease agents, particularly nontyphoidal Salmonella enterica, caused 230,000 deaths in 2010, according to the World Health Organization (Havelaar et al., 2015). Therefore, there is an urgent need to establish a rapid, sensitive, and specific method for detecting these 3 pathogenic bacteria specifically in milk.

At present, accurate detection of food-borne pathogens relies mainly on specific biochemical and immunological identification methods that are time-consuming and laborious (Russell et al., 1997; Gracias and McKillip, 2004). Molecular biology techniques such as PCRbased methods are widely used for the detection of food-borne pathogens because of their high specificity and sensitivity and short detection time (Mandal et al., 2011). Particularly, multiplex TaqMan real-time PCR (mRT-PCR) is used to monitor multiple fluo- 
rescent signals to avoid laboratory cross-contamination and time-consuming processes (Kawasaki et al., 2010; Kumar et al., 2013). It achieves simultaneous detection of multiple targets by using different fluorophores and quenchers (Botezatu et al., 2017). The specificity of the $5^{\prime}$ nuclease hydrolysis TaqMan probe has been shown to be higher than that of the SYBR Green dye method (Botezatu et al., 2017). However, mRT-PCR alone cannot distinguish between dead and viable bacteria, which can lead to false-positive results. To eliminate the interference of DNA from dead cells, a strategy that relies on sodium deoxycholate (SD) combined with propidium monoazide (PMA) pretreatment had been reported (Chang and Lin, 2018; Huang et al., 2018). Sodium deoxycholate is a bile salt that promotes membrane rupture of dead cells; PMA is a nucleic acid cross-linking agent that can selectively penetrate bacteria with injured cell membranes to sequester the DNA, preventing its amplification during PCR (Liu and Mustapha, 2014; Erkus et al., 2016). Wang et al. (2014a) used immunomagnetic separation combined with SDPMA and RT-PCR to detect viable E. coli $\mathrm{O} 157: \mathrm{H} 7$ in milk with a limit of detection (LOD) of $10^{2} \mathrm{cfu} / \mathrm{mL}$.

In this paper, we applied SD-PMA pretreatment in combination with mRT-PCR for the specific and quantitative detection of viable E. coli O157:H7, Cronobacter spp., and Salmonella spp. in milk and milk products. Three fluorescence probes and 3 pairs of primers were designed for the specific multiplex detection of $E$. coli O157:H7, Cronobacter spp., and Salmonella spp. We hypothesized that the combination of SD and PMA in the pretreatment process would eliminate amplification of DNA from dead cells. Detection of results for the viable cells was recorded through fluorescent emission spectra and confocal fluorescence microscopy (CFM) imaging.

\section{MATERIALS AND METHODS}

\section{Bacterial Strains and Cultural Conditions}

The bacterial strains used in this paper are listed in Table 1. All strains were cultured in Luria-Bertani medium overnight at $37^{\circ} \mathrm{C}$ with shaking at $180 \mathrm{rpm}$. The target bacteria were prepared in sterile PBS (0.01 $M, \mathrm{pH} 7.4$ ) to obtain a serial 10 -fold dilution of the cell suspensions. To obtain suspensions of dead and injured cells of E. coli O157:H7 ATCC $43888\left(10^{8} \mathrm{cfu} / \mathrm{mL}\right)$ and Cronobacter spp. CICC $21654\left(10^{8} \mathrm{cfu} / \mathrm{mL}\right)$, these were heat treated at $60^{\circ} \mathrm{C}$ for $5 \mathrm{~min}$; Salmonella spp. ATCC $13076\left(10^{8} \mathrm{cfu} / \mathrm{mL}\right)$ was heated at $55^{\circ} \mathrm{C}$ for $10 \mathrm{~min}$. Immediately after heat treatment, suspensions were cooled at $4^{\circ} \mathrm{C}$ in an ice bath for $5 \mathrm{~min}$. Combined viable and dead cells were spread on Luria-Bertani plates that were incubated at $37^{\circ} \mathrm{C}$ for $24 \mathrm{~h}$ before enumeration.

\section{Primers and TaqMan Probes Design}

The primers and TaqMan probes used in this study were designed using Oligo 6.7 software (http://www .oligo.net/) and Beacon Designer 7 software (http:// www.premierbiosoft.com/). The design of primers and probes was based on the specific genes fliC (E. coli O157:H7), cgcA (Cronobacter spp.), and invA (Salmonella spp.). Specificity comparison among the primers and probes was performed using BLAST analysis (National Center for Biotechnology Information; https: //blast.ncbi.nlm.nih.gov/Blast.cgi). All primers and probes were synthesized by Sangon Biotech (Shanghai, China). The oligonucleotide sequences of primers and probes are listed in Table 2. All experimental results were performed using a CFX96 Touch Real-Time PCR Detection System (Bio-Rad Laboratories, Hercules, $\mathrm{CA})$.

\section{DNA Extraction and mRT-PCR Assay}

Bacterial DNA was extracted using the boiling water method. The samples were incubated in a boiling water bath for $15 \mathrm{~min}$ and then immediately placed on ice at $4^{\circ} \mathrm{C}$ for $5 \mathrm{~min}$. Next, the treated samples were centrifuged at $12,000 \times g$ for $5 \mathrm{~min}$ at room temperature to obtain the supernatant, which contained the genomic DNA. The supernatant was stored at $-20^{\circ} \mathrm{C}$ before use.

The mRT-PCR assay was conducted in a CFX96 Touch real-time PCR detection system, with a final volume of $25 \mu \mathrm{L}$ containing $12.5 \mu \mathrm{L}$ of premixed Ex Taq probe (TaKaRa Biotech Co. Ltd., Dalian, China), $1 \mu \mathrm{L}$ of each primer $(10 \mu M)$ for $f l i C, c g c A$, and $i n v A$, $0.5 \mu \mathrm{L}$ of each probe $(10 \mu M)$ for fliC, $c g c A$, and $i n v A$, and $2 \mu \mathrm{L}$ of each target bacteria DNA. The mRT-PCR conditions were as follows: preincubation at $95^{\circ} \mathrm{C}$ for 5 min, followed by 40 cycles of denaturation at $95^{\circ} \mathrm{C}$ for $15 \mathrm{~s}$, and annealing at $60^{\circ} \mathrm{C}$ for $1.5 \mathrm{~min}$. The mRT-PCR assay was performed in triplicate parallel analysis in 8 -tube strips. Sterile water replaced the DNA templates for negative controls to ensure the absence of contamination in the tubes. All data and results were analyzed with Bio-Rad CFX Manager software (Bio-Rad Laboratories).

\section{Optimization of SD Concentration}

The treatment steps were based on a previous report (Wang et al., 2014b). The SD stock solution (10\%, wt/ vol) was prepared by dissolving SD in $0.1 \%$ (wt/vol) 
Table 1. Target and nontarget bacterial strains and results of the PCR

\begin{tabular}{|c|c|c|c|c|c|c|}
\hline No. & Bacterial strain & Strain ID & Source $^{1}$ & \multicolumn{3}{|c|}{$\mathrm{PCR}^{2}$} \\
\hline 1 & Cronobacter sakazakii & 29544 & ATCC & - & - & + \\
\hline 3 & Cronobacter turicensis & 24178 & CICC & - & - & + \\
\hline 4 & Cronobacter condimenti & 24184 & CICC & - & - & + \\
\hline 5 & Cronobacter dublinensis & 24179 & CICC & - & - & + \\
\hline 9 & Cronobacter spp. & 21654 & CICC & - & - & + \\
\hline 10 & Cronobacter spp. & 45401 & $\mathrm{CMCC}$ & - & - & + \\
\hline 11 & Cronobacter spp. & YC633B & - & - & - & + \\
\hline 12 & Salmonella enteritidis & 13076 & ATCC & + & - & - \\
\hline 13 & Salmonella typhimurium & 13311 & ATCC & + & - & - \\
\hline 14 & Salmonella typhimurium & 50115 & $\mathrm{CMCC}$ & + & - & - \\
\hline 20 & Staphylococcus aureus & 26001 & $\mathrm{CMCC}$ & - & - & - \\
\hline 21 & Staphylococcus aureus & 26002 & $\mathrm{CMCC}$ & - & - & - \\
\hline 22 & Staphylococcus aureus & 26003 & $\mathrm{CMCC}$ & - & - & - \\
\hline 23 & Staphylococcus aureus & 25923 & ATCC & - & - & - \\
\hline 24 & Staphylococcus aureus & 7907 & - & - & - & - \\
\hline 25 & Bacillus cereus & 14579 & ATCC & - & - & - \\
\hline 26 & Pseudomonas aeruginosa & 10104 & $\mathrm{CMCC}$ & - & - & - \\
\hline 27 & Listeria monocytogenes & 13932 & ATCC & - & - & - \\
\hline 28 & Listeria monocytogenes & 54007 & CMCC & - & - & - \\
\hline 29 & Listeria seeligeri & 35967 & ATCC & - & - & - \\
\hline
\end{tabular}

${ }^{1}$ ATCC = American Type Culture Collection (Manassas, VA); CICC = Center of Industrial Culture Collection (Beijing, China); CMCC = China Medical Culture Collection (Beijing, China) $--=$ laboratory separation and identification; JX-CDC = Jiang Xi Province Center for Disease Control and Prevention (Nanchang, China).

${ }^{2}$ Result (+/-) indicates positive and negative signals for the invA, fliC, and cgcA genes specific for Salmonella spp., E. coli O157:H7, and Cronobacter spp.

peptone water. The suspensions of dead and injured bacteria in the exponential phase were centrifuged at $12,000 \times g$ for $3 \mathrm{~min}$ at room temperature and the resulting pellets were suspended in sterile PBS (0.01 $M, \mathrm{pH} 7.4$ ) at different concentrations of SD: 0, 0.05, $0.10,0.25$, and $0.50 \%$. The suspensions were mixed by vortexing at $180 \mathrm{rpm}$ and incubated at $37^{\circ} \mathrm{C}$ for 30 min before the PMA treatment (described below). At the end of these processes, the bacterial DNA was extracted for RT-PCR analysis.

\section{Verification and Optimization of PMA Treatment}

A $1 \mathrm{mg} / \mathrm{mL}$ PMA stock solution was prepared by dissolving $1 \mathrm{mg}$ of PMA in $20 \%$ dimethyl sulfoxide (DMSO) and stored at $-20^{\circ} \mathrm{C}$ in the dark. Suspen-

Table 2. Primers and probes used in the real-time PCR

\begin{tabular}{|c|c|c|c|}
\hline Target bacteria & $\begin{array}{l}\text { Target } \\
\text { gene }\end{array}$ & Primer and probe sequence $\left(5^{\prime} \rightarrow 3\right)$ & $\begin{array}{l}\text { GenBank } \\
\text { accession no. }\end{array}$ \\
\hline Escherichia coli $\mathrm{O} 157: \mathrm{H} 7$ & $f l i C$ & $\begin{array}{l}\text { TCAGAATCGGAGTTAGTCCCTGT } \\
\text { GTAACGCCAACGACGGTATTT } \\
\text { HEX-CACGAATACGCTGTAAGTTGTTGT-BHQ1 }\end{array}$ & JX847136.1 \\
\hline Cronobacter spp. & $\operatorname{cgcA}$ & $\begin{array}{l}\text { TCTGGCTTATGGCTATCTTCCC } \\
\text { TCCGCAATGTTGTCCTCAGC } \\
\text { TexasRed-AACGCATCGCTTGCCGAGCTGGA-BHQ2 }\end{array}$ & CP012253.1 \\
\hline
\end{tabular}


sions of viable and dead bacteria $\left(10^{8} \mathrm{cfu} / \mathrm{mL}\right)$ were subjected to SD pretreatment as described above, and the PMA stock solution was added to obtain final concentrations of $0,5,10,15$, and $20 \mu \mathrm{g} / \mathrm{mL}$, respectively. After incubating the samples for $5 \mathrm{~min}$ in the dark with occasional mixing, they were placed on ice and exposed to a $500-\mathrm{W}$ halogen source for 5 min. During the exposure period, the tubes containing the samples were placed approximately $20 \mathrm{~cm}$ from the light source and shaken every $30 \mathrm{~s}$ to ensure uniform illumination. To eliminate free PMA after PMA cross-linking, the sample tubes were centrifuged at 12,000 $\times g$ for $5 \mathrm{~min}$ and the pelleted cells were washed with PBS twice. The genomic DNA of these SD-PMA-treated cell suspensions was extracted for the RT-PCR assay.

Propidium monoazide is a high-affinity photoreactive DNA binding dye with very weak fluorescence regardless of the source of the DNA. In a bacterial assay, only the viable cells are of interest because these cause diseases, unlike dead cells. Therefore, the dead cells that absorb the PMA must be eliminated. A microplate reader (Varioskan LUX, Thermo Fisher Scientific, Waltham, MA) was used to read the fluorescence intensity after the PMA treatment. For optimization purposes, fluorescent DNA dyes were used to visually verify the effect of PMA treatment. For this experiment, mixed solutions containing 1:1 dead and viable bacteria were treated with SD and PMA accordingly. These were treated with the fluorescent DNA dye Hoescht 33342 (Keygen Biotech, Nanjing, China), washed, and fixed in $4 \%$ paraformaldehyde for $30 \mathrm{~min}$ at room temperature and mounted into glass slides containing antiquenching reagents. Confocal fluorescence microscopy images were collected using an inverted Leica confocal laser scanning microscope (Leica TCS SP8 CARS, Leica Microsystems, Wetzlar, Germany) with a $100 \times$ oil objective and $3 \times$ zoom condition. Fluorescent images of bacteria stained with PMA and Hoechst 33342 were obtained at absorbance/emission wavelengths of $510 / 610 \mathrm{~nm}$ and $425 / 475 \mathrm{~nm}$, respectively.

\section{Standard Curves and LOD of the SD-PMA-mRT-PCR}

Three overnight cultures of fresh target bacteria were prepared to obtain a 10 -fold serial dilution $\left(10^{7}\right.$ to $10^{1}$ $\mathrm{cfu} / \mathrm{mL}$ ) followed by SD and PMA treatment. Each reaction was amplified in triplicate, and sterile water was used instead of the template DNA to obtain the negative control. The cycle threshold $(\mathbf{C t})$ values corresponding to different bacterial concentrations were used to establish the curve.

To verify the effect of the SD-PMA-mRT-PCR method in a sample matrix, we established another standard curve using bacterial DNA extracted from artificially spiked skim milk. The skim milk was purchased from a local supermarket (Rainbow Supermarket, Nanchang, China). For this, $1 \mathrm{~g}$ of skim milk powder was mixed with $9 \mathrm{~mL}$ of PBS to form a milk homogenate. The absence of the 3 target pathogens in the homogenate was analyzed by culture methods. The milk homogenate was inoculated with E. coli O157:H7, Cronobacter spp., and Salmonella spp. at final concentrations ranging from $10^{1}$ to $10^{7} \mathrm{cfu} / \mathrm{mL}$. After treatment with SD and PMA, the isolated bacteria pellets were resuspended in $100 \mu \mathrm{L}$ of ultrapure water. Genomic DNA was extracted by the boiling water method as described above. Optimized SD-PMA-mRT-PCR conditions were applied for detection of viable target cells in artificially contaminated (spiked) samples. All experiments were conducted in triplicate. Figure 1 shows the process and principle behind the mRT-PCR detection of viable $E$. coli O157:H7, Cronobacter spp., and Salmonella spp. in artificially contaminated milk.

\section{Recovery Assessment of Viable Target Bacteria by SD-PMA-mRT-PCR}

To determine the accuracy of the proposed assay, a mixed bacterial suspension containing a known number of dead and viable bacteria was prepared. The experiments were divided into 2 groups, one of which contained $10^{6} \mathrm{cfu} / \mathrm{mL}$ viable bacteria and the other a mixture of $10^{7} \mathrm{cfu} / \mathrm{mL}$ dead bacteria (identified using the culture method) and $10^{6} \mathrm{cfu} / \mathrm{mL}$ viable bacteria. The 2 groups were treated with SD and PMA as described above, and DNA samples from each group were extracted for mRT-PCR assay. The Ct values were used for recovery assessment.

\section{Statistical Analysis}

All data are expressed as means \pm standard deviations. Data from the optimized SD-PMA-mRT-PCR assays were analyzed by one-way ANOVA. Statistical analysis and standard deviation calculations were carried out by using Excel software (Microsoft Office 2010 for Windows, Microsoft Corp., Redmond, WA). Drawings were done with GraphPad Prism 6 (GraphPadPrism Software Inc., San Diego, CA) and SigmaPlot 12.5 software (Systat Software GmbH, Erkrath, Germany).

\section{RESULTS}

\section{Verification of Primers and Probes}

To evaluate the specificity and accuracy of primers and probes used in this study, mRT-PCR was used to perform melting curve analysis of the amplicons. As 
shown in Figure 2A, all 3 pair of primers generated separate single melting peaks in the mRT-PCR reaction. Furthermore, 3 strong fluorescence signals from the TaqMan-based mRT-PCR reaction indicated that all primers and probes achieved simultaneous, efficient, and accurate amplifications (Figure 2B).

\section{Optimization of mRT-PCR Assay and SD Treatment of Bacteria}

The concentration and annealing temperature of each pair of primers and probes was optimized. The results showed that optimum conditions were $0.4 \mu M$ for $f l i C$, $c g c A$, and $i n v A$ primers and $0.2 \mu M$ for $\mathrm{P}-f l i C, \mathrm{P}-c g c A$ and $\mathrm{P}$-invA (probes) at an annealing temperature at $60^{\circ} \mathrm{C}$ (data not shown). The mRT-PCR measurement was performed using a $\mathrm{Ct}$ value.

Before PMA treatment was administered, we determined the most suitable SD concentration to assess the ability of SD to enhance membrane penetrability on dead and membrane-injured cells without affecting the viable cells. As shown in Figure $3 \mathrm{~A}$, the $\mathrm{Ct}$ value obtained from E. coli O157:H7 detection first increased and then decreased with increasing SD concentration from 0 to $0.50 \%$. The $\mathrm{Ct}$ value reached its peak at a SD concentration of $0.1 \%$, indicating that a $0.1 \%$
SD concentration was the optimum concentration for the detection of $E$. coli $\mathrm{O} 157: \mathrm{H} 7$ without interference from injured and dead cells before the PMA treatment. Similarly, a $0.25 \%$ SD treatment for Cronobacter spp. (Figure 3B) and 0.1\% SD treatment for Salmonella spp. (Figure 3C) were obtained. To inhibit the detection of injured and dead cells without a negative effect on viable cells, a $0.1 \%$ SD concentration was chosen as the optimum condition for later studies.

\section{Optimization of PMA Treatment on Bacteria}

We established the most appropriate PMA concentration that did not affect viable cells to assess the ability of PMA to inhibit the detection of dead bacteria DNA after SD treatment. As shown in Figure 4A, after the PMA treatment of dead E. coli O157:H7 cells, we observed an increase in Ct value at 0 to $10 \mu \mathrm{g} /$ $\mathrm{mL}$, which reached a plateau at 10 to $20 \mu \mathrm{g} / \mathrm{mL}$ PMA. Thus, a PMA concentration of $10 \mu \mathrm{g} / \mathrm{mL}$ allowed detection of viable E. coli $\mathrm{O} 157: \mathrm{H} 7$ without interference from injured and dead cells after SD treatment. The same concentration of PMA was optimal for Cronobacter spp. (Figure 4B) and Salmonella spp. (Figure $4 \mathrm{C}$ ); thus, a PMA concentration of $10 \mu \mathrm{g} / \mathrm{mL}$ was used in the subsequent studies.
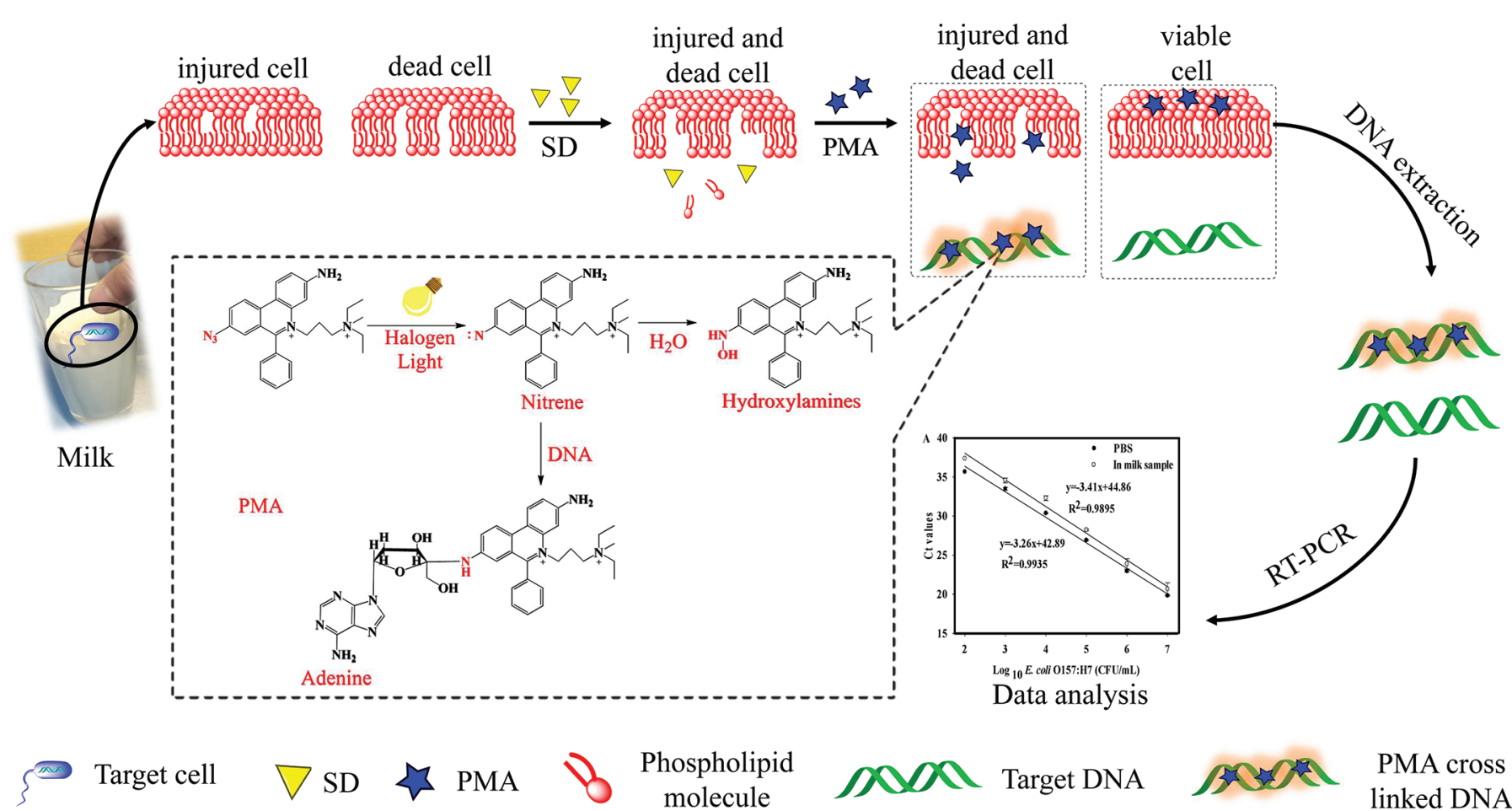

PMA cross linked DNA

Figure 1. Working principle of the sodium deoxycholate (SD)-propidium monoazide (PMA)-multiplex real-time (mRT)-PCR assay for simultaneous detection of Salmonella spp., Escherichia coli O157:H7, and Cronobacter spp. in milk. 

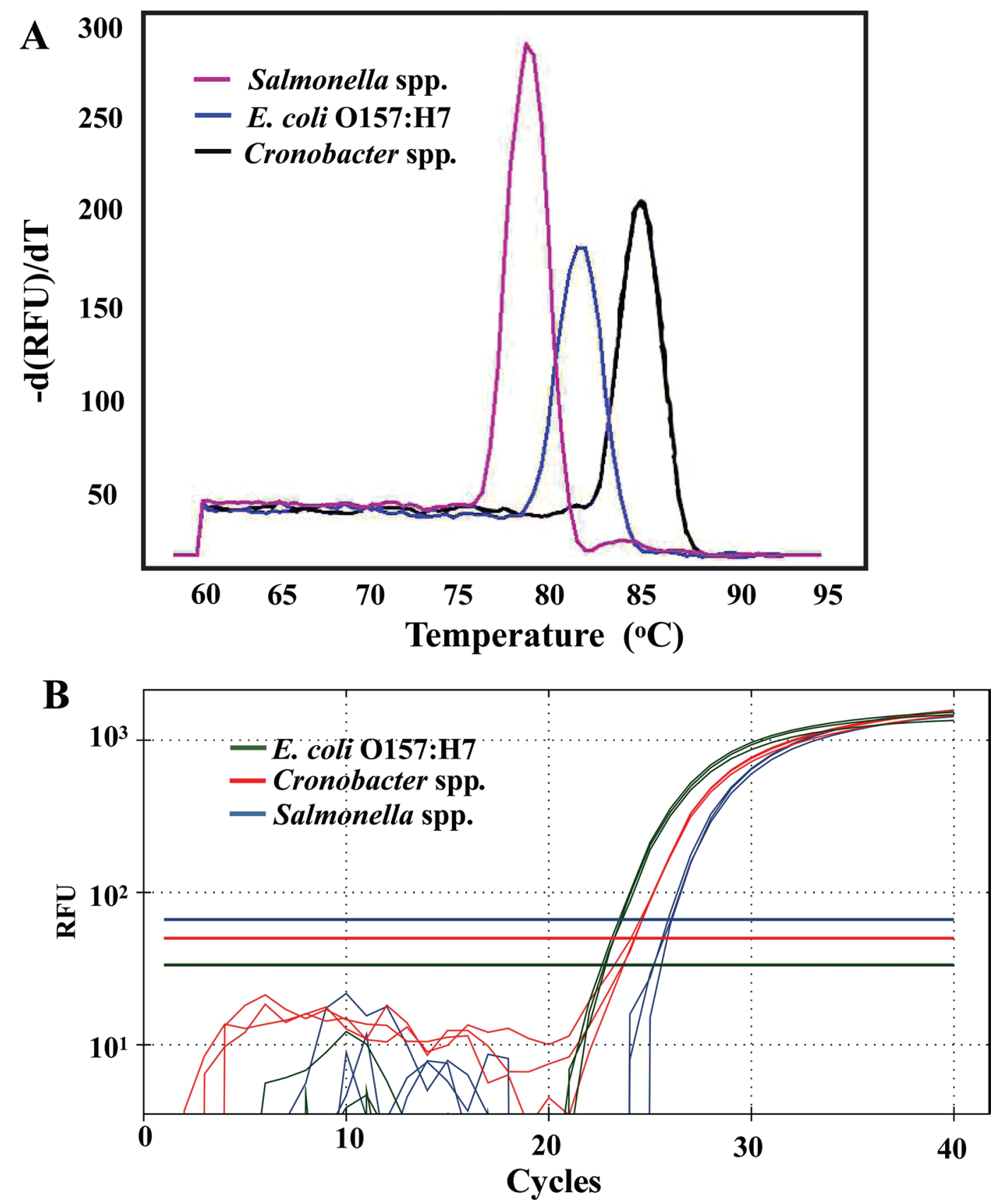

Figure 2. Verification of primers and probes: (A) melting peaks of the 3 pairs of primers (Table 2) during PCR amplification; and (B) amplification curves (relative fluorescence units, RFU) of the 3 pairs of probes for detection of Salmonella spp., Escherichia coli O157:H7, and Cronobacter spp. in milk. $-\mathrm{d}(\mathrm{RFU}) / \mathrm{dT}=$ the negative first derivative of the RFU. Horizontal lines in panel B are baseline thresholds.

\section{Verification of PMA Treatment Effect}

According to the spectral properties of PMA, the absorption and emission wavelengths after binding to DNA/RNA are 510 and $610 \mathrm{~nm}$, respectively. As shown in Figure 5, fluorescence intensity reached a maximum at $610 \mathrm{~nm}$ in dead bacteria and was close to zero in viable bacteria. Imaging was obtained using CFM to validate the effects of the PMA treatment. In Figure 6, each bacterium tagged with PMA or Hoescht 33342 emitted the corresponding fluorescence, with red indicating dead bacteria (Figure 6B) and blue indicating viable bacteria (Figure 6C), which were merged in Figure $6 \mathrm{D}$. These results indicated that PMA successfully cross-linked DNA from dead bacteria and did not affect the signals for viable bacteria. 
E. coli $\mathrm{O} 157: \mathrm{H} 7$

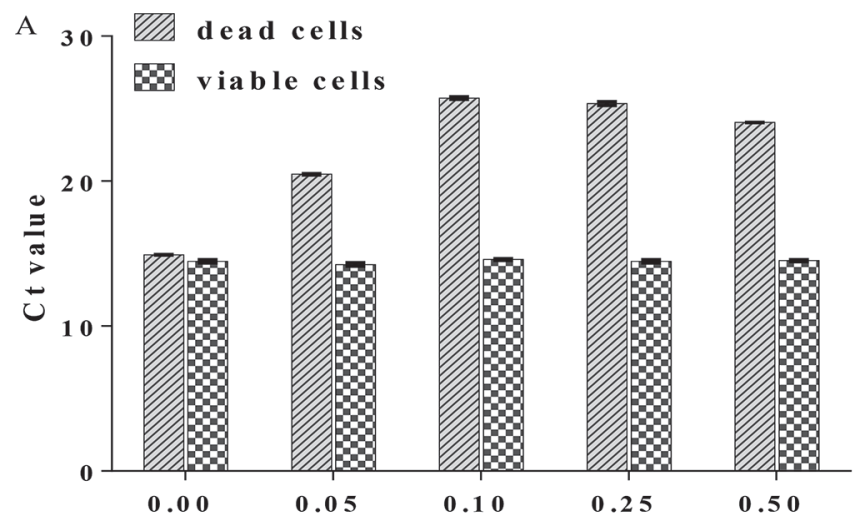

Cronobacter spp.

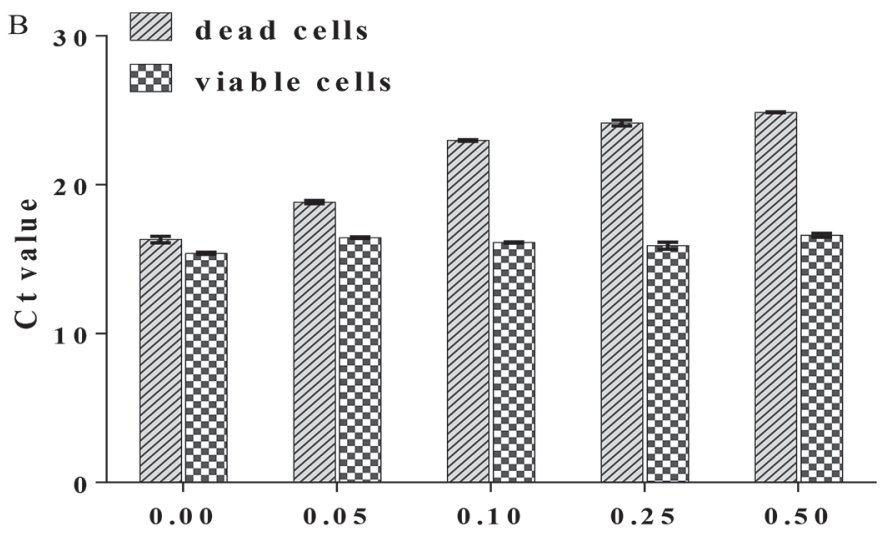

Salmonella spp.

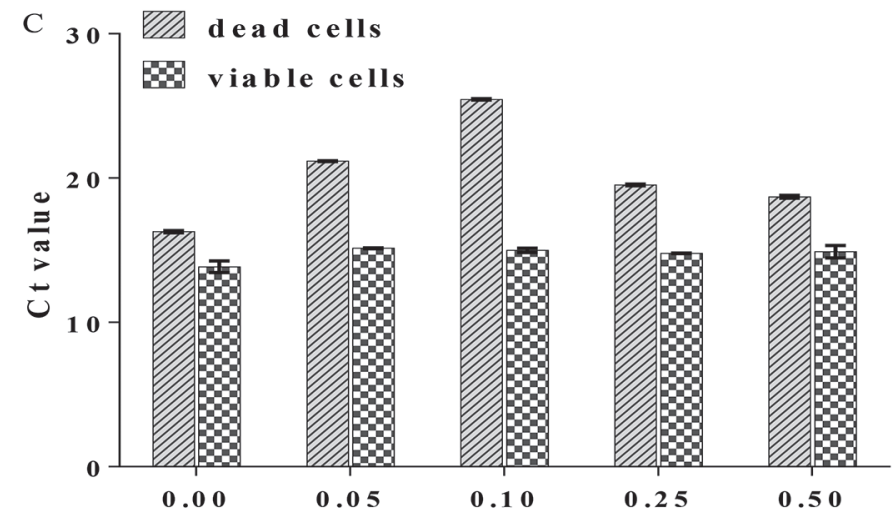

Sodium d e xycholate (\%)

Figure 3. Optimization of concentration of sodium deoxycholate (SD) for detection of (A) Escherichia coli O157:H7, (B) Cronobacter spp., and (C) Salmonella spp. Each bar represents the average cycle threshold $(\mathrm{Ct})$ value of the real-time PCR in triplicates; error bars represent SD.

\section{E. coli 0157:H7}

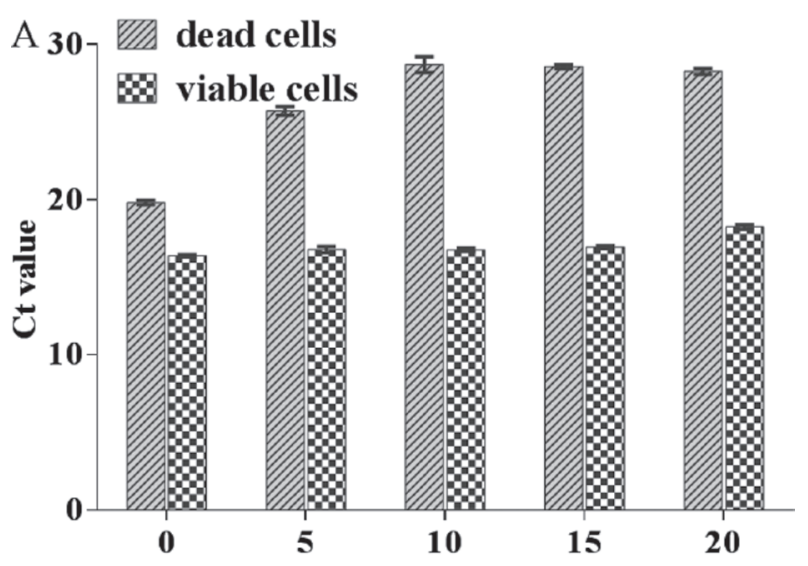

\section{C. sakazakii}

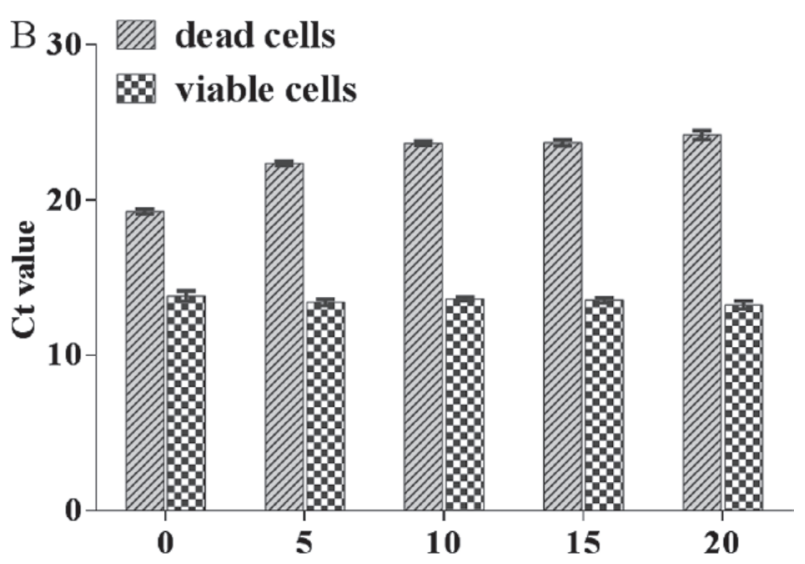

Salmonella spp.

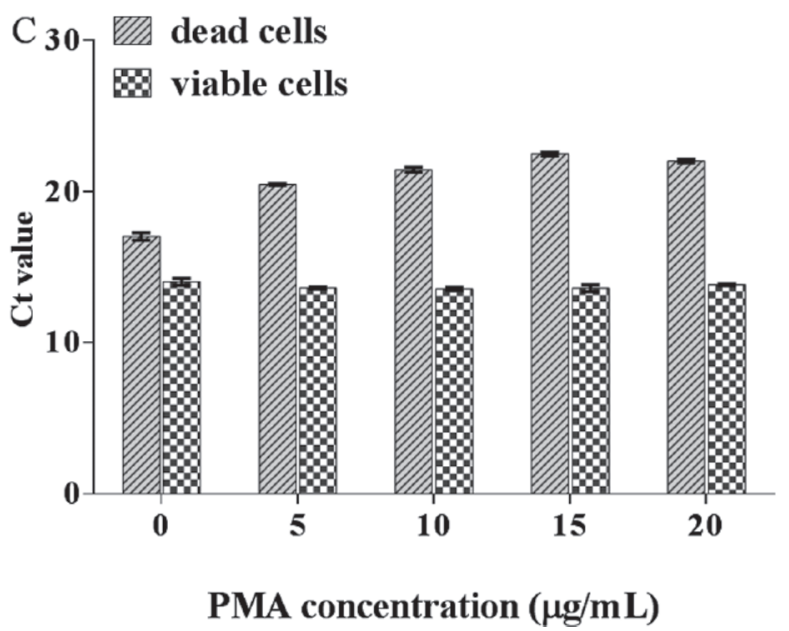

Figure 4. Optimization of concentration of propidium monoazide (PMA) for detection of (A) Escherichia coli O157:H7, (B) Cronobacter spp., and (C) Salmonella spp. Each bar represents the average cycle threshold $(\mathrm{Ct})$ value of the real-time PCR in triplicates; error bars represent SD. 
E. coli 0157:H7
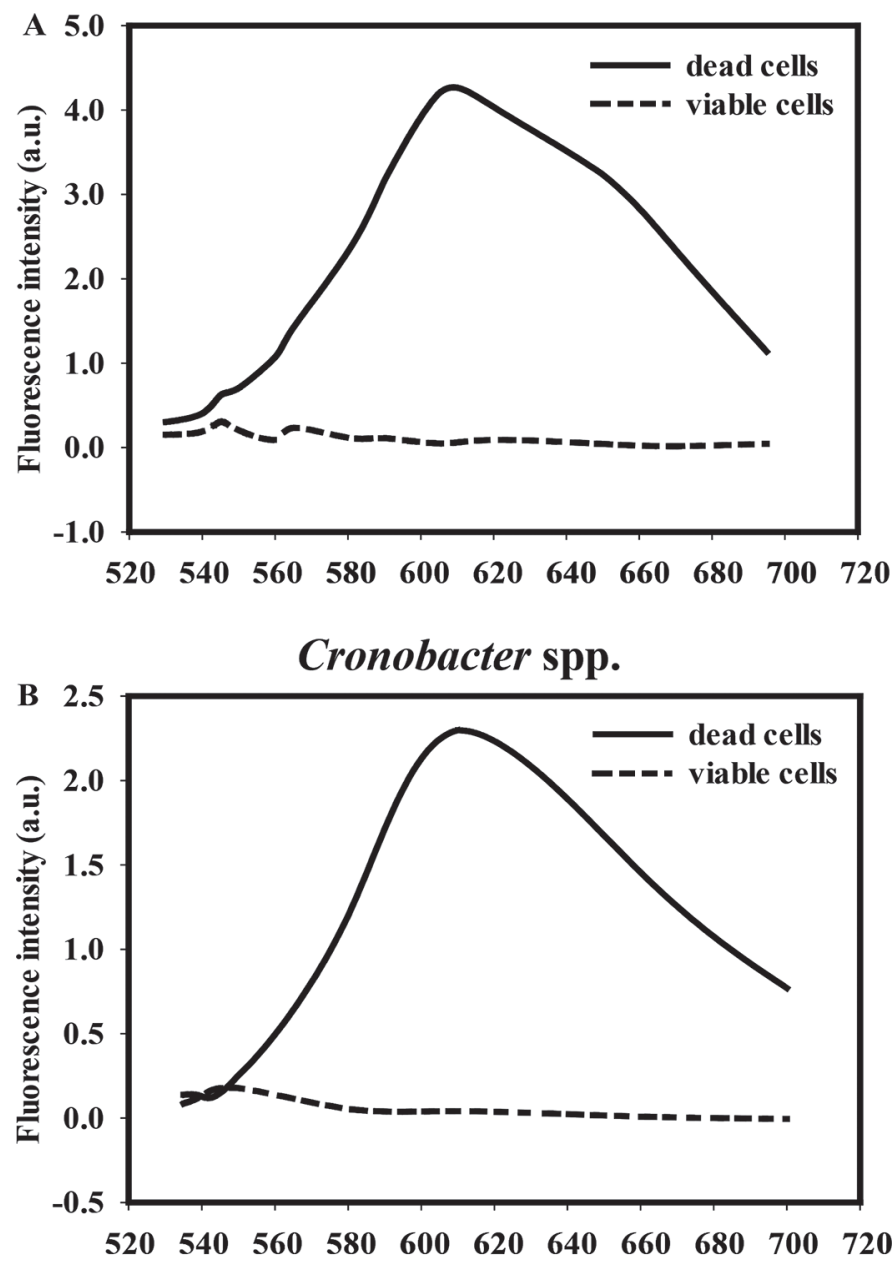

Salmonella spp.

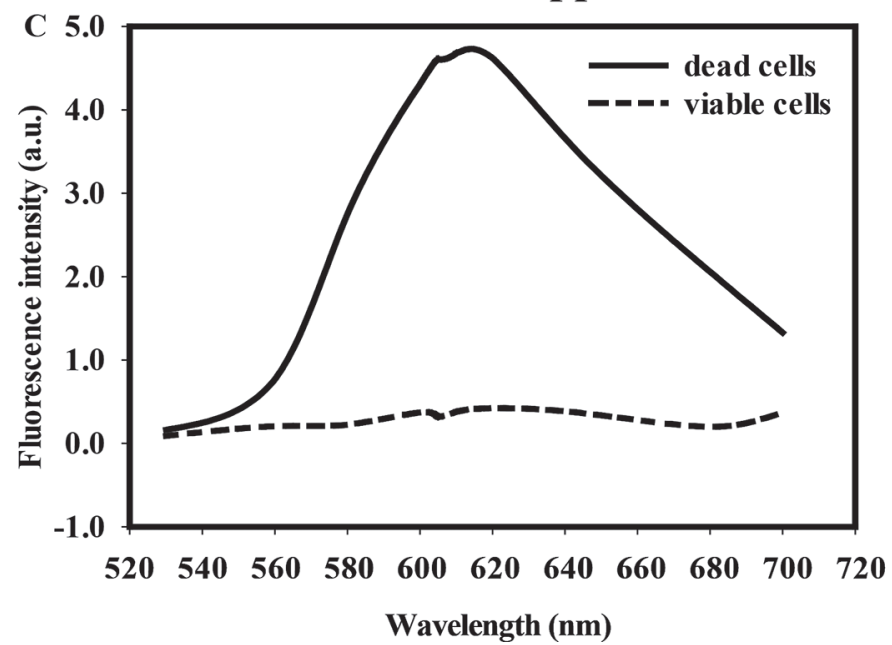

Figure 5. Verification of the effect of propidium monoazide (PMA) treatment. Fluorescent emission spectra (excited by a 510-nm UV lamp) for detection of (A) Escherichia coli O157:H7, (B) Cronobacter spp., and (C) Salmonella spp.

\section{Standard Curves and LOD of the mRT-PCR}

Standard curves were established by using the optimized SD-PMA-mRT-PCR assay to determine viable E. coli O157:H7, Cronobacter spp., and Salmonella spp. concentrations. As shown in Figure 7 , the standard curves gave linear correlations: $\mathrm{R}^{2}=0.9935$ for $E$. coli O157:H7, $\mathrm{R}^{2}=0.9914$ for Cronobacter spp., and $\mathrm{R}^{2}=$ 0.9919 for Salmonella spp. The LOD were $10^{2} \mathrm{cfu} / \mathrm{mL}$ for E. coli O157:H7, Cronobacter spp., and Salmonella spp. in pure culture. To verify the feasibility of this method to test actual samples, standard curves were established for detection of target bacteria in artificially contaminated milk. In Figure 7, standard curves for each of the bacteria showed linear correlations: $\mathrm{R}^{2}=$ 0.9895 for $E$. coli O157:H7, $\mathrm{R}^{2}=0.9948$ for Cronobacter spp., and $\mathrm{R}^{2}=0.9856$ for Salmonella spp. A similar LOD of $10^{2} \mathrm{cfu} / \mathrm{mL}$ was determined for $E$. coli O157:H7, Cronobacter spp., and Salmonella spp. There was no significant difference in signals obtained using the SD-PMA-mRT-PCR detection of the 3 pathogens in pure culture and in artificially contaminated milk. Therefore, the method can be used to simultaneously detect these 3 pathogenic bacteria without interference from the milk components.

\section{Recovery Assessment of Viable Bacteria by $m R T-P C R$}

To determine the dependability of this SD-PMAmRT-PCR method, we analyzed mixed bacteria at high concentrations $\left(10^{7} \mathrm{cfu} / \mathrm{mL}\right.$ dead bacteria and $10^{6} \mathrm{cfu} /$ $\mathrm{mL}$ viable bacteria). Mean $\mathrm{Ct}$ values obtained from the mixture and the pure viable cells were used to calculate the recovery. As shown in Figure 8, the recovery of the 3 target bacteria was between 100 and 107\%. Even in the presence of high concentrations of dead bacteria, the viable bacteria could be detected accurately using the method developed in this study.

\section{Specificity of the $m R T-P C R$}

The specificity of the mRT-PCR assay was evaluated using 29 strains including 19 target bacteria, as listed in Table 1. Among the 19 target bacteria, 11 strains were Cronobacter spp., 5 strains were Salmonella spp., and 3 strains were E. coli O157:H7. The amplification results indicated that $c g c A$ can be used to specifically detect strains of Cronobacter spp., and similar results were found for $i n v A$ and $f l i C$; none of the non-target strains yielded positive results. The results revealed that the SD-PMA-mRT-PCR assay developed in this study was specific to E. coli O157:H7, Cronobacter spp., and Salmonella spp. 
A
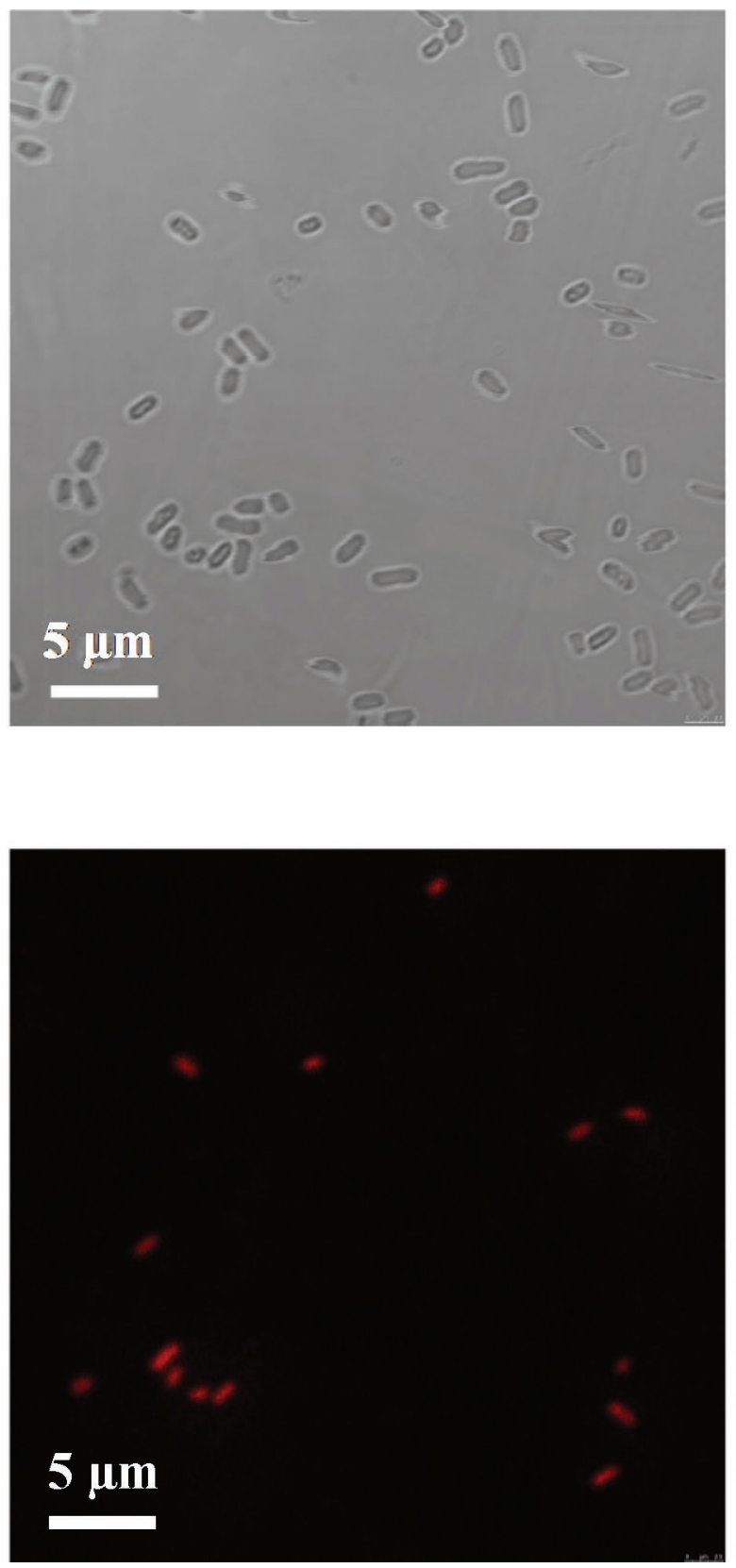
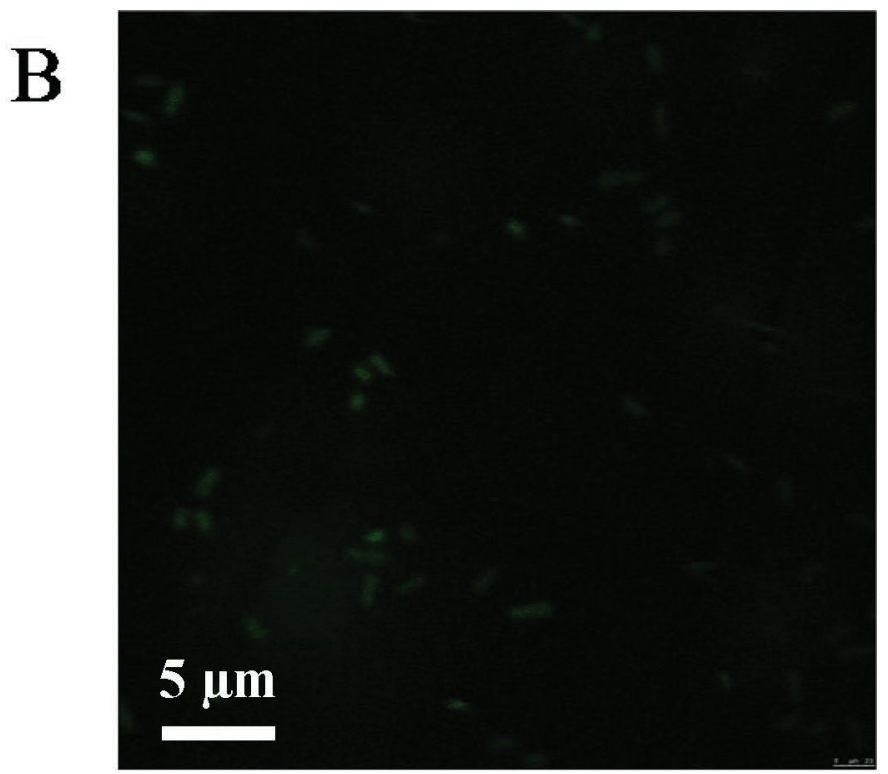

$\mathrm{D}$

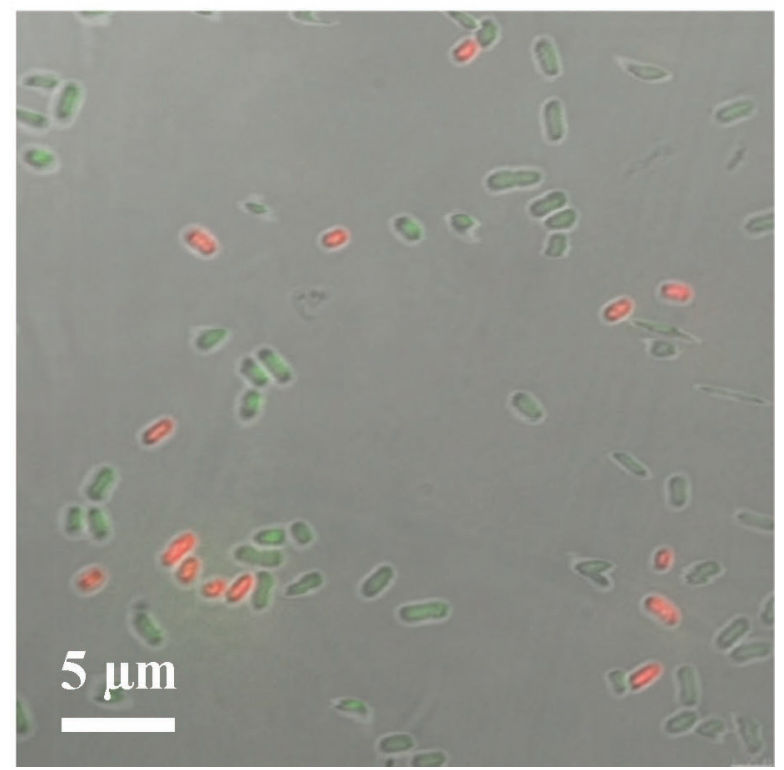

Figure 6. Confocal fluorescence microscopy images of double-stained Escherichia coli O157:H7: (A) with light microscopy with no stain, (B) stained with Hoechst 33342, (C) stained with propidium monoazide (PMA), and (D) merged image (Hoechst 33342 and PMA).

\section{DISCUSSION}

The mRT-PCR assay has been widely used as an effective technology in the quantitative detection of pathogenic bacteria (Deora et al., 2015; Li et al., 2015) because of several advantages, including high sensitivity, wide detection linear range, and good detection accuracy and repeatability. However, RT-PCR analysis fails to distinguish between surviving, dead, and injured bacteria, and has not been shown to detect multiple bacteria in one reaction tube at the same time. Previous studies have shown that SD pretreatment combined with PMA was an effective method for detecting live cells (Wang et al., 2014b; Zhou et al., 2017). Combining SD and PMA with the mRT-PCR platform as described here shows potential for the simultaneous detection of 3 viable target bacterial pathogens.

It has been reported that, under normal conditions, injured cells are dormant and do not cause infection and harm to their hosts (Morgan et al., 1993). Previous 

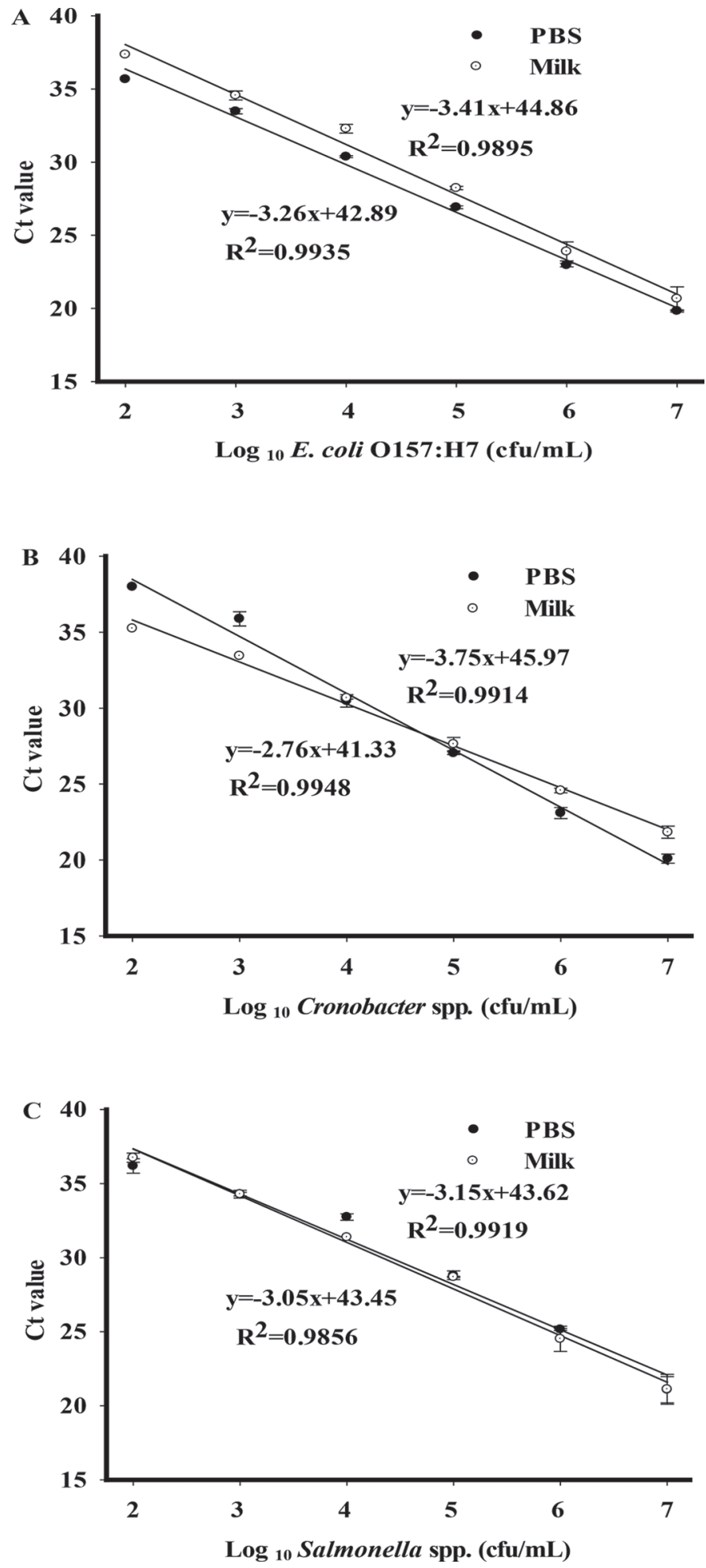

Figure 7. Establishment of standard curves for sodium deoxycholate and propidium monoazide multiplex real-time PCR. (A) Escherichia coli O157:H7; (B) Cronobacter spp.; and (C) Salmonella spp. The DNA templates were from a 10 -fold serial dilution of bacteria. Each point represents the average cycle threshold $(\mathrm{Ct})$ value from triplicate analysis. Error bars represent SD.

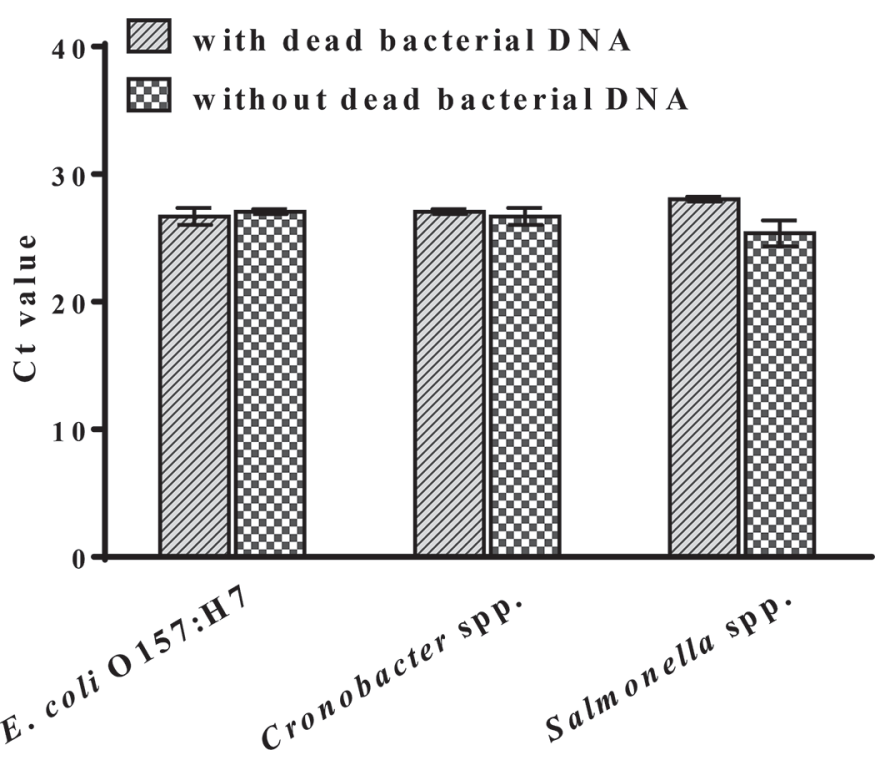

Figure 8. Recovery of viable Escherichia coli O157:H7, Cronobacter spp., and Salmonella spp. by sodium deoxycholate (SD)-propidium monoazide (PMA)-multiplex real-time (mRT)-PCR assay. Each bar represents the average cycle threshold $(\mathrm{Ct})$ value from triplicate analysis; error bars represent SD.

research had successfully used PMA pretreatment with RT-PCR to detect viable food-borne pathogens in milk (Wang et al., 2014b; Dong et al., 2018). However, PMA treatment does not completely inhibit DNA amplification from dead and injured bacteria due to the ineffective barrier function of injured cell membranes. To eliminate PMA sequestration of DNA from dead cells, we used the SD pretreatment to enhance the PMA method (Zhou et al., 2016). The optimum concentrations of $0.10 \%$ SD and $10 \mu \mathrm{g} / \mathrm{mL}$ PMA effectively inhibited DNA amplification of dead and membraneinjured cells but did not affect the signal from intact cells.

Propidium monoazide can be used not only to distinguish between dead and viable bacteria, but also as a fluorescent dye that binds to DNA to verify the effect of treatment. However, fluorescence intensity significantly increases after binding the nucleic acid (Nocker et al., 2006; Fittipaldi et al., 2012) from both dead and viable cells. Previous reports only studied optimization of PMA treatment without verification of how it affects the bacteria (Wang et al., 2014b). In this study, we applied this feature of PMA to determine the ability to distinguish between viable and dead bacteria. Compared with viable bacteria, the DNA of dead bacteria that was cross-linked to PMA showed significant fluorescence intensity at $610 \mathrm{~nm}$. In addition, we used double fluorescent markers to successfully distinguish between dead and viable bacteria by CFM 
imaging. This technique confirmed visually that PMA was able to penetrate dead bacteria but not the viable bacteria, which allowed for specific detection of target viable bacteria.

Design of primers and probes is crucial for the development of sensitive, specific mRT-PCR. In the present report, we selected $f l i C$ (encoding flagellin protein of $E$. coli O157:H7), cgcA (the diguanylate cyclase gene of Cronobacter spp.), and invA (type III secretion system protein InvA of Salmonella spp.) genes for the PCR (Collazo and Galán, 1997; McNeilly et al., 2008; Hu, 2018). According to the literature, fliC is specific to E. coli $\mathrm{O} 157: \mathrm{H} 7$ and does not exist in other serotypes (Narang et al., 2009). The invA gene is a virulence gene encoding an invading protein that has been shown to be unique to Salmonella spp. (Rahn et al., 1992). The $c g c A$ gene can be used to detect all 7 recognized species within the Cronobacter genus (Carter et al., 2013; Yan and Fanning, 2015). Three pairs of primers were designed to have similar melting temperature values $\left(\sim 60^{\circ} \mathrm{C}\right)$, whereas that of the probes was about $10^{\circ} \mathrm{C}$ higher to ensure efficient hybridization with the template (Thornton and Basu, 2011). The size of the amplified fragment was between 80 and $200 \mathrm{bp}$ to ensure efficient amplification. $\mathrm{Li}$ et al. (2015) reported that amplicon sizes of 80,123, and 149 bp had good detection efficiency. These primers and probes did not cross-react as indicated by a software simulation that was confirmed through the RT-PCR verification. Therefore, the 3 pairs of primers and probes chosen for the SD-PMA-mRT-PCR assay developed in this study could be used for simultaneous and specific detection of the 3 viable target bacterial pathogens in milk.

\section{CONCLUSIONS}

We established a rapid and accurate multiplex RTPCR combined with SD and PMA pretreatment platform (SD-PMA-mRT-PCR) for simultaneous detection of 3 viable organisms: E. coli O157:H7, Cronobacter spp., and Salmonella spp. in milk. The reaction conditions were optimized to specifically detect $10^{2} \mathrm{cfu} / \mathrm{mL}$ of E. coli O157:H7, $10^{2} \mathrm{cfu} / \mathrm{mL}$ of Cronobacter spp., and $10^{2} \mathrm{cfu} / \mathrm{mL}$ of Salmonella spp. in milk. The specific and rapid SD-PMA-mRT-PCR method developed in this study holds promise for the simultaneous quantitative detection of food-borne pathogen contamination in milk.

\section{ACKNOWLEDGMENTS}

The work was supported by the Research Foundation from State Key Laboratory of Food Science and Technology, Nanchang University, China (No. SKLF-
ZZB-201720), and we are very grateful for the Jiangxi Key Research and Development Plan Project, Jiangxi, China (20171BBG70074), and Jiangxi Food and Drug Administration Science and Technology Plan, Jiangxi, China (2017SP06), for financial support.

\section{REFERENCES}

Amani, J., A. Ahmadpour, A. A. Imani Fooladi, and S. Nazarian. 2015. Detection of E. coli O157:H7 and Shigella dysenteriae toxins in clinical samples by PCR-ELISA. Braz. J. Infect. Dis. 19:278284.

Bhunia, A. K. 2018. Foodborne Microbial Pathogens: Mechanisms and Pathogenesis. 2nd ed. Springer Science+Business Media, New York, NY.

Botezatu, I. V., I. O. Panchuk, A. M. Stroganova, A. I. Senderovich, V. N. Kondratova, V. P. Shelepov, and A. V. Lichtenstein. 2017. TaqMan probes as blocking agents for enriched PCR amplification and DNA melting analysis of mutant genes. Biotechniques 62:62-68.

Carter, L., L. A. Lindsey, C. J. Grim, V. Sathyamoorthy, K. G. Jarvis, G. Gopinath, C. Lee, J. A. Sadowski, L. Trach, M. Pava-Ripoll, B. A. McCardell, B. D. Tall, and L. Hu. 2013. Multiplex PCR assay targeting a diguanylate cyclase-encoding gene, $c g c A$, to differentiate species within the genus Cronobacter. Appl. Environ. Microbiol. 79:734-737.

Chang, C. W., and M. H. Lin. 2018. Optimization of PMA-qPCR for Staphylococcus aureus and determination of viable bacteria in indoor air. Indoor Air 28:64-72.

Coburn, B., G. A. Grassl, and B. B. Finlay. 2007. Salmonella, the host and disease: a brief review. Immunol. Cell Biol. 85:112-118.

Collazo, C. M., and J. E. Galán. 1997. The invasion-associated type III system of Salmonella typhimurium directs the translocation of Sip proteins into the host cell. Mol. Microbiol. 24:747-756.

Deora, A., B. D. Gossen, S. Amirsadeghi, and M. R. McDonald. 2015. A multiplex qPCR assay for detection and quantification of Plasmodiophora brassicae in soil. Plant Dis. 99:1002-1009.

Dong, L., H. Liu, L. Meng, M. Xing, J. Wang, C. Wang, H. Chen, and N. Zheng. 2018. Quantitative PCR coupled with sodium dodecyl sulfate and propidium monoazide for detection of viable Staphylococcus aureus in milk. J. Dairy Sci. 101:4936-4943.

Erkus, O., V. C. de Jager, R. T. Geene, I. van Alen-Boerrigter, L. Hazelwood, S. A. van Hijum, M. Kleerebezem, and E. J. Smid. 2016. Use of propidium monoazide for selective profiling of viable microbial cells during Gouda cheese ripening. Int. J. Food Microbiol. 228:1-9.

Fittipaldi, M., A. Nocker, and F. Codony. 2012. Progress in understanding preferential detection of live cells using viability dyes in combination with DNA amplification. J. Microbiol. Methods 91:276-289.

Gracias, K. S., and J. L. McKillip. 2004. A review of conventional detection and enumeration methods for pathogenic bacteria in food. Can. J. Microbiol. 50:883-890.

Havelaar, A. H., M. D. Kirk, P. R. Torgerson, H. J. Gibb, T. Hald, R. J. Lake, N. Praet, D. C. Bellinger, N. R. de Silva, N. Gargouri, N. Speybroeck, A. Cawthorne, C. Mathers, C. Stein, F. J. Angulo, and B. Devleesschauwer. 2015. World Health Organization global estimates and regional comparisons of the burden of foodborne disease in 2010. PLoS Med. 12:e1001923.

Hu, L. 2018. Prevalence of curli genes among Cronobacter species and their roles in biofilm formation and cell-cell aggregation. Int. J. Food Microbiol. 265:65-73.

Huang, Z., J. Zheng, C. Shi, and Q. Chen. 2018. Flow cytometry-based method facilitates optimization of PMA treatment condition for PMA-qPCR method. Mol. Cell. Probes 40:37-39.

Kawasaki, S., P. M. Fratamico, N. Horikoshi, Y. Okada, K. Takeshita, T. Sameshima, and S. Kawamoto. 2010. Multiplex real-time polymerase chain reaction assay for simultaneous detection and quantification of Salmonella species, Listeria monocytogenes, and 
Escherichia coli O157: H7 in ground pork samples. Foodborne Pathog. Dis. 7:549-554.

Kumar, A., S. Grover, and V. K. Batish. 2013. Application of multiplex PCR assay based on uidR and $\mathrm{fliCH}^{7}$ genes for detection of Escherichia coli O157: H7 in milk. J. Gen. Appl. Microbiol. 59:11-19.

Li, H., H. Xin, and S. F. Y. Li. 2015. Multiplex PMA-qPCR assay with internal amplification control for simultaneous detection of viable Legionella pneumophila, Salmonella typhimurium, and Staphylococcus aureus in environmental waters. Environ. Sci. Technol. 49:14249-14256.

Liu, Y., and A. Mustapha. 2014. Detection of viable Escherichia coli O157:H7 in ground beef by propidium monoazide real-time PCR. Int. J. Food Microbiol. 170:48-54.

Mandal, P. K., A. K. Biswas, K. Choi, and U. K. Pal. 2011. Methods for rapid detection of foodborne pathogens: An overview. Am. J. Food Technol. 6:87-102.

McNeilly, T. N., S. W. Naylor, A. Mahajan, M. C. Mitchell, S. McAteer, D. Deane, D. G. Smith, J. C. Low, D. L. Gally, and J. F. Huntley. 2008. Escherichia coli O157: H7 colonization in cattle following systemic and mucosal immunization with purified $\mathrm{H} 7$ flagellin. Infect. Immun. 76:2594-2602.

Morgan, J. A., G. Rhodes, and R. Pickup. 1993. Survival of nonculturable Aeromonas salmonicida in lake water. Appl. Environ. Microbiol. 59:874-880.

Narang, N., P. M. Fratamico, G. Tillman, K. Pupedis, and W. C. Cray Jr.. 2009. Performance comparison of a $f{ } C_{\mathrm{h} 7}$ real-time PCR assay with an $\mathrm{H} 7$ latex agglutination test for confirmation of the $\mathrm{H}$ type of Escherichia coli O157: H7. J. Food Prot. 72:2195-2197.

Nocker, A., C.-Y. Cheung, and A. K. Camper. 2006. Comparison of propidium monoazide with ethidium monoazide for differentiation of live vs. dead bacteria by selective removal of DNA from dead cells. J. Microbiol. Methods 67:310-320.

Painter, J. A., R. M. Hoekstra, T. Ayers, R. V. Tauxe, C. R. Braden, F. J. Angulo, and P. M. Griffin. 2013. Attribution of foodborne illnesses, hospitalizations, and deaths to food commodities by using outbreak data, United States, 1998-2008. Emerg. Infect. Dis. 19:407-415.
Rahn, K., S. De Grandis, R. Clarke, S. McEwen, J. Galan, C. Ginocchio, R. Curtiss Iii, and C. Gyles. 1992. Amplification of an invA gene sequence of Salmonella typhimurium by polymerase chain reaction as a specific method of detection of Salmonella. Mol. Cell. Probes 6:271-279.

Russell, S., N. Cox, J. Bailey, and D. Fung. 1997. Miniaturized biochemical procedures for identification of bacteria. J. Rapid. Methods Automat. Microbiol. 5:169-177.

Sulovská, K., E. Fišerová, M. Chvosteková, and M. Adámek. 2017. Appropriateness of gait analysis for biometrics: Initial study using FDA method. Measurement 105:1-10.

Thornton, B., and C. Basu. 2011. Real-time PCR (qPCR) primer design using free online software. Biochem. Mol. Biol. Educ. 39:145154.

Wang, H., C. O. Gill, and X. Yang. 2014a. Use of sodium lauroyl sarcosinate (sarkosyl) in viable real-time PCR for enumeration of Escherichia coli. J. Microbiol. Methods 98:89-93.

Wang, L., P. Li, Z. Zhang, Q. Chen, Z. P. Aguilar, H. Xu, L. Yang, F. Xu, W. Lai, and Y. Xiong. 2014b. Rapid and accurate detection of viable Escherichia coli O157: H7 in milk using a combined IMS, sodium deoxycholate, PMA and real-time quantitative PCR process. Food Control 36:119-125.

Yan, Q., and S. Fanning. 2015. Strategies for the identification and tracking of Cronobacter species: an opportunistic pathogen of concern to neonatal health. Front Pediatr. 3:38.

Yu, S., L. Yan, X. Wu, F. Li, D. Wang, and H. Xu. 2017. Multiplex PCR coupled with propidium monoazide for the detection of viable Cronobacter sakazakii, Bacillus cereus, and Salmonella spp. in milk and milk products. J. Dairy Sci. 100:7874-7882.

Zhou, B., B. Chen, X. Wu, F. Li, P. Yu, Z. P. Aguilar, H. Wei, and H. $\mathrm{Xu}$. 2016. A new application of a sodium deoxycholate-propidium monoazide-quantitative PCR assay for rapid and sensitive detection of viable Cronobacter sakazakii in powdered infant formula. J. Dairy Sci. 99:9550-9559.

Zhou, B., T. Liang, Z. Zhan, R. Liu, F. Li, and H. Xu. 2017. Rapid and simultaneous quantification of viable Escherichia coli O157: H7 and Salmonella spp. in milk through multiplex real-time PCR. J. Dairy Sci. 100:8804-8813. 